\title{
Spanish Teaching Assistants' Attitudes towards Communicative Language Teaching
}

\author{
Dr. Comfort Pratt \\ Associate Professor \\ Department of Teacher Education \\ College of Education \\ Texas Tech University \\ USA
}

\begin{abstract}
Among the reasons discussed in the literature for difficulties in the implementation of communicative language teaching (CLT) in second language classrooms are the attitudes of teachers towards the approach. In an effort to ascertain the nature of this problem in lower-level college programs, this study investigated the attitudes of teaching assistants of Spanish towards the approach by means of an attitude scale. The results revealed that the teaching assistants held favorable attitudes towards the principles of CLT, especially with regard to the thematic groups corresponding to group/pair work and the role and contribution of learners. They also demonstrated low favorability towards error correction. Pearson product-moment correlation analyses revealed that there was no correlation between their attitudes and their native or non-native speaker status, or their years of experience, but there was a weak positive correlation between their attitudes and the amount of professional training they had received.
\end{abstract}

Keywords: Communicative approach, communicative competence, communicative language teaching (CLT), second language acquisition, teaching assistants' attitudes, teaching assistant training

\section{Introduction}

CLT came into existence in Europe in the 1960s as a result of a reaction to Situational Language Teaching, which emphasized the mastery of structures in situation-based activities and required accuracy in pronunciation and grammar. Proponents for the change such as Henry Widdowson and Christopher Candlin wanted to shift the focus from knowledge of structures to communicative competence, using as the basis for their argument the work of British functional linguists such as Michael Halliday and John Firth, American sociolinguists such as William Labov, Dell Hymes, and John Gumperz, and philosophers such as John Austin and John Searle. The process of change continued in the 1970s as a result of widespread reaction to both first language (LI) and second language (L2) teaching methods, which emphasized the teaching of grammatical forms with little or no attention to how people use language in everyday situations. Audiolingualism had been declared an unsuccessful methodology for various reasons, including the fact that students were unable to transfer audiolingual skills to real life communication, and they described the learning experience as boring and unrewarding. CLT therefore came into being as an approach that emphasized the production of students who were communicatively competent, and it has greatly influenced the practice of modern foreign language teaching.

Dell Hymes, who proposed the term communicative competence, defines it as "a speaker's knowledge of the total set of rules and conventions governing the skilled use of language in a society" (Matthews 2007: 65). His focus was the use of language in a social context, that is, language as social behavior. Canale and Swaine (1980) also define communicative competence as a synthesis of an underlying system of knowledge and skill needed for communication. Putting more emphasis on ability, Savignon defines communicative competence as "the ability to function in a truly communicative setting, that is, in a dynamic exchange in which linguistic competence must adapt itself to the total informational input, both linguistic and palalinguistic, of one or more interlolcutors" (1972: 8). 
While there is evidence of the effectiveness of CLT as an approach to L2 teaching, there is also evidence that some teachers resist it (Littlewood 2007; Meskill \& Anthony 2007; Nobuyoshi \& Ellis 1993; Pratt 2008; Richards \& Rodgers 2014; Sáfár \& Kormos 2008; Savignon \& Wang 2003).

Among others, teachers' attitudes have been identified as a contributing factor to the difficulties encountered in the implementation of the approach (Chang 2011; Gokcora \& Eveyik-Aydin 2011; Karavas-Doukas 1996; Rahimi \& Naderi 2014). Given that contexts influence attitudes, some researchers have stressed the importance of tailoring pedagogy to particular settings (Chang 2011, Ellis 1996; Holliday 1994; Kramsch \& Sullivan 1996; Miller \& Aldred 2000). However, most of the research has centered on EFL contexts.

\section{Underlying Principles of CLT}

According to Canale and Swaine (1980), communicative competence has four dimensions, namely, grammatical competence, sociolinguistic competence, discourse competence, and strategic competence. Grammatical competence refers to what Noam Chomsky calls linguistic competence, and includes lexical items and knowledge of phonology, morphology, syntax, and semantics. Sociolinguistic competence refers to an understanding of the social context in which communication takes place, that is, knowledge of role relationships, shared beliefs, and information between participants. Discourse competence refers to the interpretation of individual message elements in terms of their interconnectedness and how meaning is represented in relationship to the entire discourse or text. In other words, it is knowledge of rules for the combination of utterances or of factors governing the creation of cohesion and coherence. Strategic competence refers to the coping strategies that participants use to initiate, terminate, maintain, repair, and redirect communication-the verbal and non-verbal strategies they use to compensate for breakdowns in communication. They include paraphrasing, circumlocution, repetition, evasive talk, shifts in register and style, hesitation, avoidance, etc. Subsequently, CLT classroom procedures are based on a set of principles that reflect a communicative view of language and language learning.

Learning is done through authentic and meaningful communication rather than through the customary method of formal analysis and translation. It is a process of creative construction and involves trial and error (Richards \& Rodgers 2014). It is done through direct practice and in the sociocultural context of its use (Savignon 1983). It is learner-centered and experience-based, with the ideal curriculum consisting of well-selected experiences that take into account individual learners' needs and goals. CLT learners manage their own learning. The teacher's role is that of a facilitator and an independent participant (Richards \& Rodgers 2014). Littlewood (2010) also describes the teacher as a guide and a co-communicator. Learning, here, means acquiring the linguistic means to perform functions, which, according to Halliday (1978), are instrumental, regulatory, interactional, personal, heuristic, imaginative, and representational. The underlying learning theory includes the communication principle, which states that activities that involve real communication promote learning; the task principle, which states that activities in which language is used to carry out meaningful tasks promote learning; and the meaningfulness principle, which states that language which is meaningful to the learner supports the learning process. Instructors must put these features of the CLT classroom into practice by means of communicative activities in which "the learner uses the linguistic repertoire he has learnt, in order to communicate specific meanings for specific purposes" (Littlewood 1981: 17). These activities are best carried out through pair and group work.

Littlewood (1981) distinguished between two categories of communicative activities, namely, functional communication activities and social interaction activities. Functional communication activities emphasize the functional aspect of language, that is, getting meaning across as effectively as possible to fulfill communicative demands. Social interaction activities provide a more clearly defined social context than the functional activities. They approximate more closely the kind of communication situations encountered outside the classroom, where language is a form of social behavior in addition to being a functional instrument. Learners experience a wider range of communicative needs in situations more similar to those in the real world and under the influence of more varied and clearly defined social conditions. Materials are crucial in the CLT classroom as the activities are the tools used to achieve teaching and learning and the accompanying materials in part determine their success. The materials help establish the context for communication. They are text-based, task-based, or realia, meaning they are real-life items that make the activities authentic. Pratt (2008) provides a variety of examples of these activities accompanied by the required materials in a format that is ready for classroom use. Very limited research has been done on teachers' attitudes towards CLT, including teaching assistants who teach languages other than English. 
Studies on teachers of English as a foreign language (EFL) in different contexts show that the teachers have favorable attitudes towards CLT (Ahmad \& Rao 2013; Ansarey 2012; Chang 2011; Jafari et al. 2015; Derakhshan \& Torabi 2015; Karavas-Doukas 1996; Lee 2014; Ngoc \& Iwashita 2012; Raissi et al. 2013; Ozsevik 2010). Investigations of teachers' knowledge, implementation, training, and skills, however, find gaps and recommend more training (Borg 2011; Lugo Cruz 2018; Wyatt \& Borg 2011). Although these studies provide very useful information, it goes without saying that more investigation is required on the teaching of languages other than English in different contexts and at different levels. Therefore, this study focuses specifically on attitudes of TAs of Spanish in the United States. Given that the TAs are usually the ones who are responsible for teaching lowerlevel college courses where students have not yet achieved communicative competence, it is vital to understand their attitudes towards CLT. Research shows that teachers' attitudes play a crucial role in revealing their thinking and what influence that may have on their practices (Ansarey 2012; Chang 2011; Derakhshan \& Torabi 2015; Jafari et al. 2015; Karavas-Doukas 1996). As Richards and Lockhart (1994) argue, "It [The view of teaching that involves cognitive, affective and behavioral dimension] is based on the assumption that what teachers do is a reflection of what they know and believe, and that teacher knowledge and 'teacher thinking' provide the underlying framework or schema which guides the teacher's classroom actions" (p. 29). Thus, as Carless (2003) states, "If teachers' views are not sufficiently taken account of, the already challenging nature of implementing something new may be exacerbated" (p. 485). The research questions are as follows:

1. Do teaching assistants of Spanish have favorable attitudes towards CLT?

2. How do the teaching assistants' backgrounds affect their attitudes towards CLT?

\section{Methodology}

\subsection{Participants}

Participants were graduate TAs from four universities in the south of the United States who worked for departments where graduate students teach the lower-level Spanish courses and have implemented CLT. From the 23 responses received from an online survey that was sent to approximately 80 TAs, 8 did not fill out the survey in full, thus the sample consists of the 15 who completed it. The participants were assigned pseudonyms to protect their anonymity. There were 7 native speakers (Benito, Diana, Elena, Hortensia, Jorge, Marta and Norma) and 8 non-native speakers (Angela, Chase, Frank, Gertrude, Kate, Isabel, Lisa and Oliver). There were 13 Ph.D. students and 2 Master's students (Chase and Benito). One participant (Jorge) was majoring in Spanish linguistics, 2 were specializing in Bilingual Education (Angela and Kate), and 12 were studying literature. They were all teaching or had taught college or high school classes. Eight of them had taught for 1 to 5 years, 4 of them for 6 to 10 years, and 3 had 11 to 15 years teaching experience. Table 1 presents some information about the participants.

Table 1: Summary of Participants

\begin{tabular}{|l|l|l|l|l|}
\hline Name & $\begin{array}{l}\text { Native/Non-native } \\
\text { Speaker }\end{array}$ & Major & Level Taught & $\begin{array}{l}\text { Using CLT in } \\
\text { Classroom }\end{array}$ \\
\hline Angela & Non-native & $\begin{array}{l}\text { Bilingual } \\
\text { Education }\end{array}$ & 1 st year college & Yes \\
\hline Benito & Native & Literature & II, III \& IV high school & No \\
\hline Chase & Non-native & Literature & $2^{\text {nd }}$ year college & Yes \\
\hline Diana & Native & Literature & $2^{\text {nd }}$ year college & Yes \\
\hline Elena & Native & Literature & $2^{\text {nd }}$ year college & No \\
\hline Frank & Non-native & Literature & $1^{\text {st }} 2^{\text {nd }} \& 3^{\text {rd }}$ year college & Yes \\
\hline Gertrude & Non-native & Literature & $2^{\text {nd }} \& 3^{\text {rd }}$ year college & Yes \\
\hline Hortensia & Native & Literature & $1^{\text {st }} \& 2^{\text {nd }}$ year college & Yes \\
\hline Isabel & Non-native & Literature & $1^{\text {st }}$ year college & Yes \\
\hline Jorge & Native & Linguistics & $1^{\text {st }}$ year college & Yes \\
\hline Kate & Non-native & Literature & $1^{\text {st }} 2^{\text {nd }}, 3^{\text {rd }} \& 4^{\text {th }}$ year college & Yes \\
\hline Lisa & Non-native & $\begin{array}{l}\text { Bilingual } \\
\text { Education }\end{array}$ & $2^{\text {nd }}, 3^{\text {rd }} \& 4^{\text {th }}$ year college & Yes \\
\hline Marta & Native & Literature & $1^{\text {st }}$ year college & Yes \\
\hline Norma & Native & Literature & $4^{\text {th }}$ year college & Yes \\
\hline Oliver & Non-native & Literature & $1^{\text {st }}$ year college & Yes \\
\hline
\end{tabular}




\subsection{Procedure}

An online survey questionnaire was administered to the participants via Qualtrics. Parts I (items 1 to 22) and III (47 to 65) were developed by the investigator and solicited background information about the participants and their classroom practices, respectively. Part II, consisting of items 23 to 46, comprised the 24-item KaravasDoukas (1996) Communicative Approach Attitude Scale. The scale consists of statements covering the main aspects of the communicative approach mentioned above under "Underlying Principles of CLT," and seeks to determine attitudes towards specific principles of the approach. It is presented on a five-point Likert scale: $1=$ Strongly Disagree, 2 = Disagree, 3 = Uncertain, $4=$ Agree, and $5=$ Strongly Agree, and it includes five subcategories covering group/pair work (4 items), the quantity and quality of error correction (4 items), the role of learners (6 items), the role of the teacher (4 items), and the place and importance of grammar (6 items). The inclusion of the attitude scale was based on the understanding that teachers' attitudes are crucial in determining the successful implementation of innovatory ideas and understanding their classroom behaviors (Karavas-Doukas 1996). Additionally, Likert-type scales tend to yield more reliable results compared to other scaling techniques (Gardner \& Smythe 1981; Gokcora \& Eveyik-Aydin 2011). The selection of this scale was due to the fact that its split-half reliability was 0.88 , which proved that it has a high level of internal consistency, which is higher than the norm of 0.85 (Karavas-Doukas 1996). For this study, the investigator used the whole of Part II of the questionnaire and some background information from Part I. The remaining items were used for other studies.

\subsection{Data Analysis}

The TAs' overall attitude scores were computed. Possible scores ranged from 120 to 24 with 120 indicating the most favorable attitude towards CLT, with a neutral point of 72. According to Karavas-Doukas (1996), the neutral point is not necessarily the midpoint between the extreme scores because a respondent can obtain a middle-of-therange score by either being uncertain about many items or by holding inconsistent or strongly favorable and strongly unfavorable attitudes towards the attitude object in question. Descriptive statistics were used to determine the mean and standard deviation of each of the principles of CLT individually and as a group. For the favorable items $(24,25,28,29,30,31,34,36,38,40,42,46)$, the scale ranged from 5 to 1 , with 5 being "Strongly Agree" and 1 being "Strongly Disagree," and for the unfavorable items (23, 26, 27, 32, 33, 35, 37, 39, 41, 43, 44, 45), the scoring was reversed, so the scale ranged from 1 to 5, with 1 being "Strongly Agree" and 5 being "Strongly Disagree." That way, the positive end of the scale was always 5, and the higher the overall score, the more positive the attitude towards CLT. The mean scores and standard deviation for the different principles were also calculated to determine where the teaching assistants had the most favorable or least favorable attitudes. In order to ascertain their attitudes with regard to the thematic groups comprising the scale, the items were divided into five groups to match the thematic groups proposed by Karavas-Doukas (1996). Finally, descriptive statistics and Pearson product-memory correlation analyses were used to determine how the TAs' backgrounds influenced their attitudes towards CLT.

\section{Results and Discussion}

\subsection{Do teaching assistants of Spanish have favorable attitudes towards CLT?}

According to Kleinsasser and Savignon (1991):"In our quest for the improvement of language teaching, we have overlooked the language teacher. Exploration ... of teachers' perceptions of what they do and why they do it, holds promise for understanding the frequently noted discrepancies between theoretical understanding of second/foreign language acquisition and classroom practice" (p. 299). Teachers' attitudes and theories affect their classroom behaviors and subsequently influence what students actually learn. Therefore, teachers' attitudes are an important factor to take into consideration when a new approach is introduced as that would be in competition with the previous approaches they have experienced or used (Freeman \& Richards 1993). In order to find out if the TAs held favorable attitudes or not towards CLT, items 23 to 46 requested indications of their attitudes regarding the main aspects of the approach. Table 2 shows their individual scores on the attitude scale. In line with findings of previous studies in other contexts, the investigator hypothesized that participants would have favorable attitudes overall but demonstrate some lack of knowledge about some of the principles. Additionally, in view of the fact that lower-level students of Spanish continue to struggle in their efforts to achieve communicative competence and the literature indicates that students coming out of U. S. foreign language undergraduate programs hardly ever achieve the Advanced Low proficiency level (Darhower 2014; Glisan 2013; Pratt 2017; Tedick 2013; Valdés et al. 2003), the investigator also expected that the breakdown of scores would show some unfavorable scores, indicating significant difficulties with some tenets of the approach. 
Table 2: Individual Scores

\begin{tabular}{|l|l|}
\hline Teaching Assistant & Score \\
\hline Oliver & 98 \\
\hline Norma & 100 \\
\hline Isabel & 79 \\
\hline Lisa & 104 \\
\hline Kate & 74 \\
\hline Jorge & 95 \\
\hline Marta & 91 \\
\hline Hortensia & 83 \\
\hline Gertrude & 86 \\
\hline Frank & 85 \\
\hline Elena & 76 \\
\hline Diana & 93 \\
\hline Chase & 98 \\
\hline Benito & 91 \\
\hline Angela & 96 \\
\hline
\end{tabular}

As shown in Table 2, all 15 TAs received scores higher than the neutral point of 72, indicating that all of them had favorable attitudes towards the communicative approach. However, the scores ranged considerably from as low as 74 to a not too high point of 104, indicating very diversified attitudes and a lack of very strong convictions. The mean score was 89.9 and the standard deviation was 9.1. Table 3 shows the mean scores of the responses as a group.

Table 3: Descriptive Statistics for all the Principles

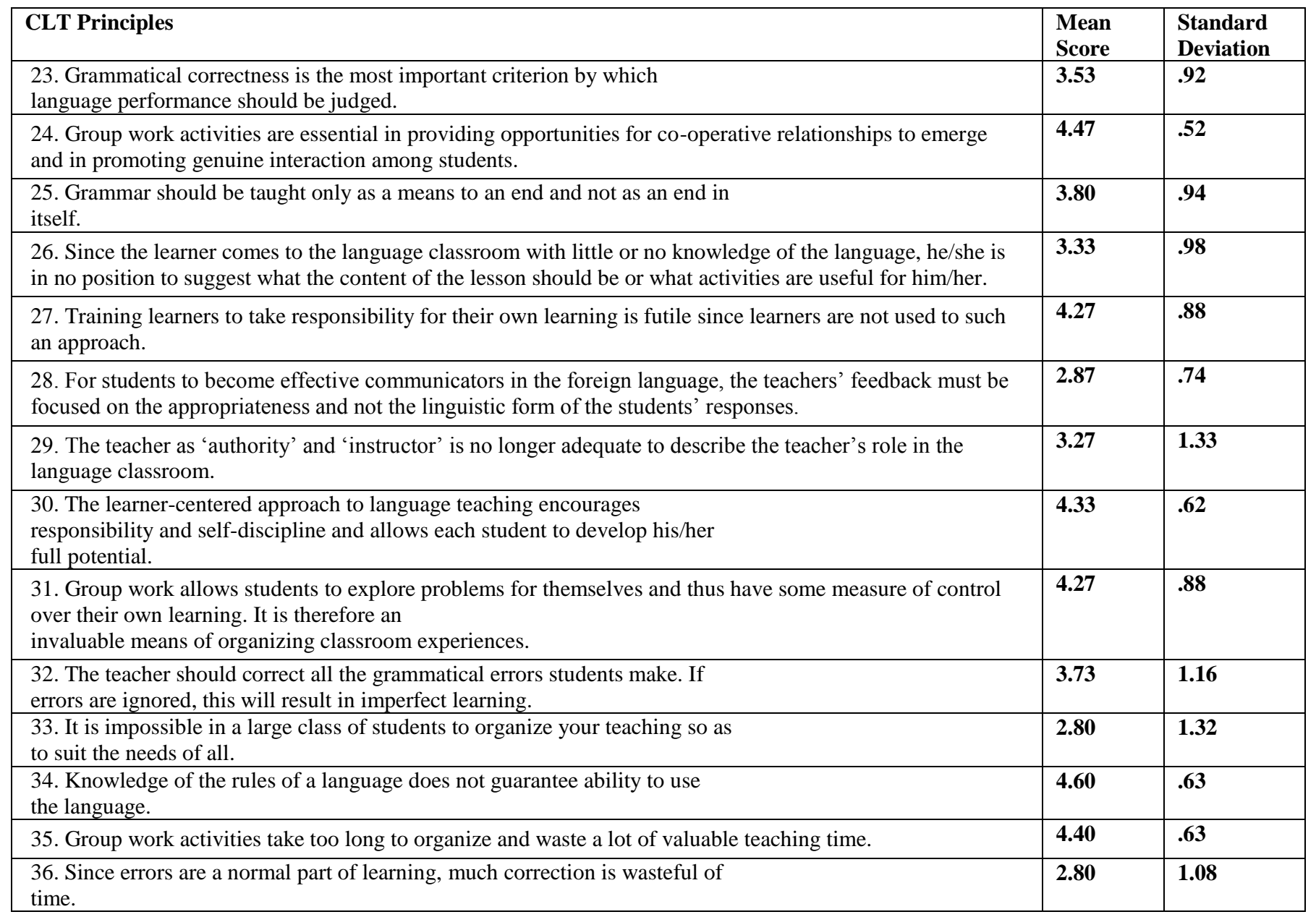




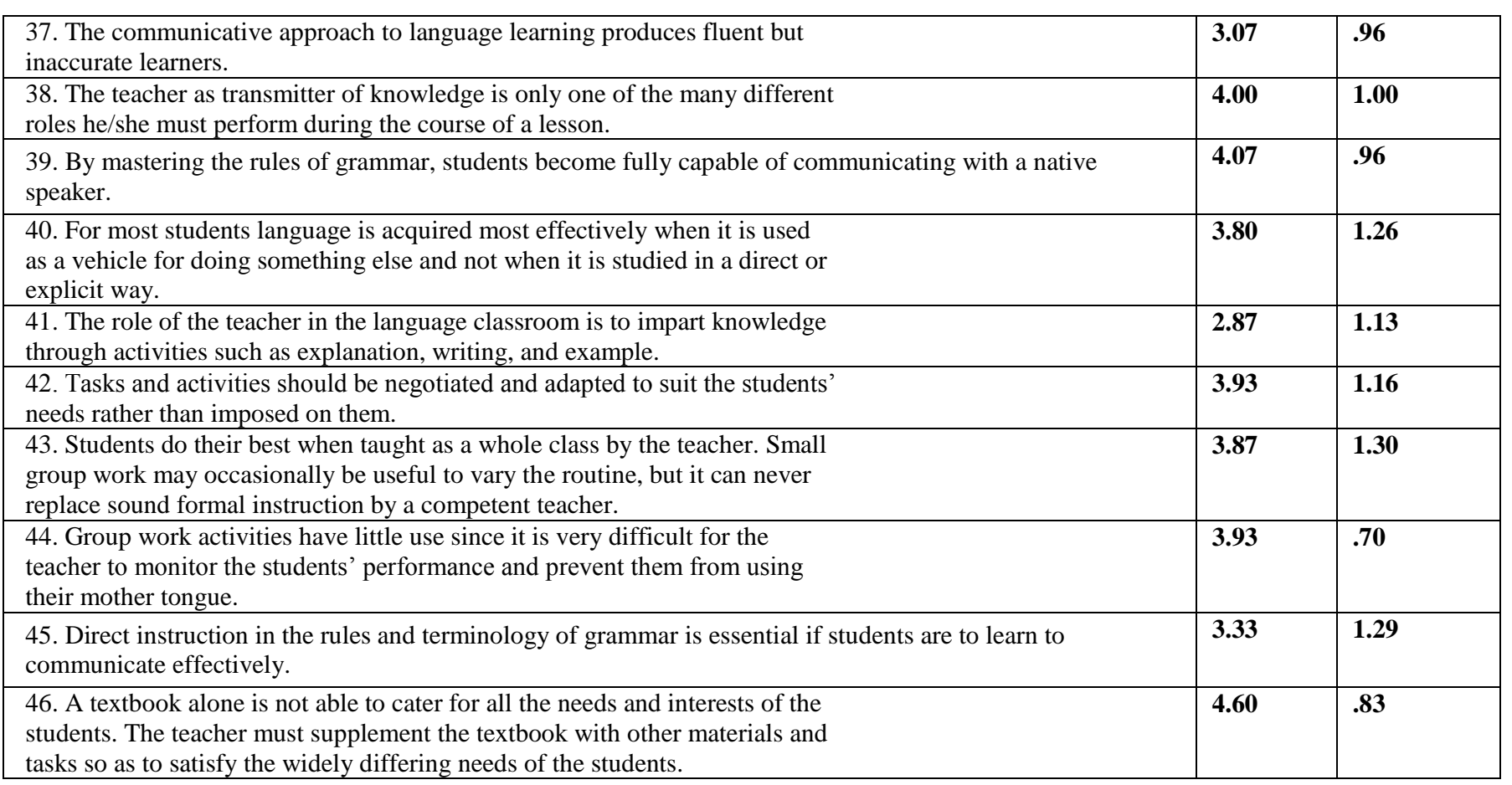

As indicated in Table 3, the principles with the highest mean scores were items 34, 46, 24, 35, 30, 27 and 31, in that order, pertaining to the place or importance of grammar, the importance of supplementary materials, group work activities, and the responsibilities of learners. The principles with the lowest mean scores were items 33,36 , 28 , and 41 , in that order, pertaining to teaching to suit the needs of students, error correction, the focus of the teacher's feedback, and the role of the teacher. This demonstrates that overall, the TAs held very favorable attitudes towards the following principles: knowledge of the rules of a language does not guarantee ability to use the language; a textbook alone is not able to cater to all the needs and interests of the students, and the teacher must supplement it with other materials and tasks so as to satisfy the widely differing needs of the students; group work activities are essential in providing opportunities for cooperative relationships to emerge and in promoting genuine interaction among students; group work activities do not waste valuable teaching time; the learnercentered approach to language teaching encourages responsibility and self-discipline and allows all students to develop their individual full potential; and training learners to take responsibility for their own learning is not futile.

On the other hand, participants held only mildly favorable attitudes towards the following principles: It is possible in a large class of students to organize your teaching so as to suit the needs of all; since errors are a normal part of learning, much correction is wasteful of time; for students to become effective communicators in a foreign language, the teacher's feedback must be focused on the appropriateness and not the linguistic form of the students' responses; and the role of the teacher in the language classroom is not to impart knowledge through activities such as explanation, writing, and example, in that order. With regard to the remaining fourteen principles, the attitude was average. Overall, favorability was high for only $25 \%$ of the principles and the vast majority received mildly favorable to favorable attitudes.

These results are similar to findings of some research on teachers' attitudes in different EFL contexts (Ahmad \& Rao 2013; Ansarey 2013; Chang 2011; Jafari et al. 2015; Karavas-Doukas 1996; Lee 2014; Ngoc \& Iwashita 2012; Raissi et al. 2013; Ozsevik 2010), which revealed that EFL teachers hold favorable attitudes towards the communicative approach. As shown in Table 4 (descriptive statistics of attitudes towards the five thematic groups), the TAs had favorable attitudes towards all the five thematic groups into which the 24 items were divided. The thematic group with the highest mean was group/pair work (4.17), followed by the role and contribution of learners in the learning process (3.82), place or importance of grammar (3.73), and the role of the teacher in the classroom (3.69). The lowest mean corresponded to quality and quantity of error correction. Jafari et al. (2015) also reported the same highest (group/pair work) and lowest (quality and quantity of error correction) means. Ngoc and Iwashita (2012) also discovered that the most favorable attitudes corresponded to group/pair work, and Chang (2011) discovered that quality and quantity of error correction had the lowest means. 
It appears, therefore, that instructors understand the importance of group/pair work activities but struggle with error correction.

Table 4: Descriptive Statistics of Attitudes Towards the Five Thematic Groups

\begin{tabular}{|l|l|l|}
\hline Thematic Group & Mean & Standard Deviation \\
\hline Group/Pair work & 4.17 & .31 \\
\hline Quality and quantity of error correction & 3.28 & .52 \\
\hline The role and contribution of learners in the learning process & 3.82 & .45 \\
\hline The role of the teacher in the classroom & 3.69 & .77 \\
\hline Place/importance of grammar & 3.73 & .55 \\
\hline
\end{tabular}

\subsection{How do the teaching assistants' backgrounds affect their attitudes towards CLT?}

\subsubsection{Native and Non-Native Speaker Status}

The implementation of CLT requires teachers to have a high proficiency level in the target language, because the approach implies new roles for teachers that include the following: using only the target language as a medium of instruction; creating group activities that provide opportunities for students to use the target language as a vehicle for doing things; assuming the role of facilitator and monitor; organizing instruction to suit the needs of students; supplementing the textbook with other materials and tasks in order to satisfy the widely differing needs of students; and providing feedback that focuses on the appropriateness of students' language use. Therefore, the investigator's hypothesis was that the non-native TAs would have less favorable attitudes towards the tenets of the approach than their native colleagues, especially with regard to the teacher's role, feedback, and classroom activities. However, as Table 5 shows, the overall mean score of the non-native speakers was slightly higher than that of the native speakers. It appears, therefore, that on the whole, the native speakers did not have more favorable attitudes towards the approach than the non-native speakers.

Table 5: Teaching Assistants' Attitude Scores on the Basis of their Native or Non-native Status

\begin{tabular}{|l|l|l|l|}
\hline Native/Non-Native Speaker & Number & Mean & SD \\
\hline Native & 7 & 89.86 & 7.97 \\
\hline Non-Native & 8 & 90 & 10.54 \\
\hline
\end{tabular}

As shown in Table 6, descriptive statistics of the scores for the five thematic groups indicated that on the whole, the native speakers had higher mean scores than the non-native speakers with regard to group/pair work $(M=4.29$, $S D=.81$ and $M=4.06, S D=.91)$, quality and quantity of error correction $(M=3.18, S D=.98$ and $M=2.94, S D=1.27)$, and the role and contribution of learners in the learning process $(M=4.12, S D=1.06$ and $M=3.90, S D=.99)$. On the other hand, on the whole, the non-native speakers had higher mean scores than the native speakers with regard to the role of the teacher in the classroom $(M=3.78, S D=1.21$ and $M=3.57, S D=1.32)$, and the place or importance of grammar $(M=4.02, S D=.89$ and $M=3.52, S D=1.09)$.

Therefore, the hypothesis was supported in the case of group/pair work and quality and quantity of error correction, but it was not supported in terms of the role of the teacher in the classroom. It appears that the nonnative TAs' proficiency levels in Spanish did not create inhibition, which indicates that they probably have positive self-efficacy beliefs about their proficiency in Spanish. This finding is important, because one of the problems faced by non-native teachers of foreign languages is the lack of adequate proficiency in the target language (Chang 2011; Jafari et al 2015; Li 1998; Tsai 2007; Valdés et al. 2003).

A closer look at the background information of the participants revealed that 4 of the 8 non-native TAs had lived in Spanish-speaking countries for 1 to 5 years and another had lived there for 6 to 10 years. The remaining 3 had never lived in a Spanish-speaking country. Additionally, 4 of the 5 who had lived in Spanish-speaking countries had also studied Spanish for 11 to 15 years and the fifth one had studied it for 6 to 10 years. The 3 who had never lived in Spanish-speaking countries had also studied Spanish for 6 to 10 years, 11 to 15 years, and 16 years or more, respectively. Therefore, the non-native speakers had experienced immersion in the target culture and/or long-term study of the language, both of which play an important role in language acquisition. Previous studies in other contexts did not investigate the effects of the participants' native and non-native speaker status on their attitudes. 
Table 6: Thematic Group Scores Based on Native and Non-Native Speaker Status

\begin{tabular}{|l|l|l|l|l|}
\hline & \multicolumn{2}{l|}{$\begin{array}{l}\text { Native } \\
\text { Speakers }\end{array}$} & $\begin{array}{l}\text { Non-Native } \\
\text { Speakers }\end{array}$ \\
\hline Thematic Group & Mean & $\begin{array}{l}\text { Standard } \\
\text { Deviation }\end{array}$ & Mean & $\begin{array}{l}\text { Standard } \\
\text { Deviation }\end{array}$ \\
\hline Group/Pair work & 4.29 & .81 & 4.06 & .91 \\
\hline Quality and quantity of error correction & 3.18 & .98 & 2.94 & 1.27 \\
\hline $\begin{array}{l}\text { The role and contribution of learners in the } \\
\text { learning process }\end{array}$ & 4.12 & 1.06 & 3.90 & .99 \\
\hline The role of the teacher in the classroom & 3.57 & 1.32 & 3.78 & 1.21 \\
\hline Place/importance of grammar & 3.52 & 1.09 & 4.02 & .89 \\
\hline
\end{tabular}

\subsubsection{Years of Experience with CLT}

Due to the fact that $80 \%$ of the participants were specializing in Spanish literature, it was not deemed useful to determine the relationship between their attitudes and their areas of specialization.With regard to experience with CLT, while years of correct implementation and improvement might impact attitude scores, years of experience with ineffective supervision and training might not have that effect. Thus, the hypothesis was that years of experience will not correlate with attitude. As shown in Table 7, the hypothesis was partially supported. The mean for the TAs who had used CLT for less than 1 year was higher $(M=97, S D=1.41)$ than the mean for those who had used the approach for 1-5 years $(M=87.89, S D=10.42)$ and 6-10 years $(M=88, S D=4.36)$, and the participant with 11-15 years had a higher score than all the other groups.

Table 7: Descriptive Statistics Based on Years of Experience with CLT

\begin{tabular}{|l|l|l|l|}
\hline Years of Experience with CLT & Number & Mean & Standard Deviation \\
\hline Less than 1 year & 2 & 97 & 1.41 \\
\hline 1-5 years & 9 & 87.89 & 10.42 \\
\hline 6-10 years & 3 & 88 & 4.36 \\
\hline 11-15 years & 1 & 100 & 0 \\
\hline
\end{tabular}

A Pearson product-moment correlation analysis was computed to assess the relationship between the TAs' attitudes towards CLT and the number of years of experience they had with CLT. There was no correlation between the two variables ( $\mathrm{r}=0$ ). This finding is similar to those of Suk-Fun (1998) and Jafari et al. (2015), who also found that the mean scores of the participants with the least amount of teaching experience were the highest among the four groups. This could be due to the fact that the new TAs are receiving better training now possibly because the trainers are now better versed in the approach.

\subsubsection{Professional Training}

Due to the crucial nature of training for teachers implementing CLT (Chang 2011; Li 1998; Liao 2003; Tsai 2007), it would be expected that the TAs who had undergone training would have higher scores than those who did not, and that the amount of training would correlate with the scores. However, due to the information the TAs revealed regarding their training, which showed many inconsistencies and a lack of serious consideration in most cases, this investigator hypothesized that the training would not make any significant difference. As Table 8 demonstrates, the mean for the TA who did not receive any training was higher $(M=98)$ than the mean for the rest of the participants.

However, among those who had undergone training, those who had taken a course in CLT, attended training sessions, and had practical experience had the highest mean $(M=92.8, S D=6.18)$, followed by those who had attended training sessions and had practical experience $(M=91.25, S D=12.69)$, and then those who had only attended training or had practical experience but not both $(M=82.25, S D=6.5)$. A Pearson product-moment correlation analysis computed to assess the relationship between the TAs' attitudes towards CLT and the amount of training they received revealed that there was a weak positive correlation $(\mathrm{r}=0.25)$ between the two variables. 
Table 8: Descriptive Statistics Based on Amount of Training

\begin{tabular}{|l|l|l|l|}
\hline Amount of Training & Number & Mean & Standard Deviation \\
\hline $\begin{array}{l}\text { Course in CLT, training sessions, } \\
\text { and practice }\end{array}$ & 6 & 92.8 & 6.18 \\
\hline Training sessions and practice & 4 & 91.25 & 12.69 \\
\hline Training sessions or practice & 4 & 82.25 & 6.5 \\
\hline None & 1 & 98 & 0 \\
\hline
\end{tabular}

These findings were not consistent with the results of Jafari et al. (2015) who reported that the highest mean corresponded to the participants who had attended the highest number of seminars and workshops $(M=84.23$, $S D=6.05)$, while the participants who never participated in seminars and workshops obtained the lowest mean score $(M=68.23, S D=3.45)$. They also obtained a significant correlation coefficient $(\mathrm{r}=0.634)$. This result was also supported by Chang (2011) who discovered a positive correlation between teachers' professional training and their attitudes towards CLT.

\section{Conclusion}

Given that the lack of communicative competence persists among lower-level college students of Spanish in spite of the plethora of information and research about CLT, the investigator aimed at examining the attitudes of the TAs who teach those courses to ascertain whether or not they had favorable attitudes towards the approach and how their backgrounds may be influencing their attitudes towards it. The results revealed the following:

1. The Spanish TAs held favorable attitudes towards CLT. Their scores were all higher than the mid-point both individually and as a group, indicating that the favorability is both at the individual and group levels. This suggests that if they are given the appropriate training and resources, they should be able to implement the approach appropriately and effectively. However, given that most of the scores ranged between mildly favorable and favorable and there seemed to be a lack of total conviction, the TAs would benefit from regular training sessions including practice, which would provide them with more knowledge and skills about CLT.

2. While the TAs had favorable attitudes towards all five thematic groups, the group with the highest mean score was group/pair work, followed by the role and contribution of learners, the place or importance of grammar, the role of the teacher, and then the quality and quantity of error correction. Given that various studies mentioned earlier have pointed to error correction as an area of difficulty among teachers in various contexts, more emphasis should be put on it in professional development programs such as training sessions, workshops, and seminars. Course developers and textbook authors should incorporate more explicit ways of handling error correction as there is a need to intensify efforts to improve the TAs' understanding of how to implement it. Due to the indispensability of group/pair work for the CLT classroom, it is a good sign that the TAs' attitudes towards it are so favorable.

3. There was no correlation between the TAs' native or non-native speaker status and their attitudes towards CLT as the non-native TAs appeared to not be inhibited by their status. This finding is important, because the low proficiency level among non-native foreign language teachers has been an issue of concern. The data further revealed that the non-native TAs had experienced immersion and long-term study of the Spanish language, which accounted for their apparent high proficiency level. Hence the recommendation that the proficiency levels of TAs be taken seriously as their ability to implement CLT depends on it. Study abroad in a target country and long-term study of the language facilitate language acquisition significantly.

4. There was no correlation between the TAs' years of experience with CLT and their attitudes towards the approach, which can be attributed to lack of adequate supervision to ensure the correct implementation of the approach, or that years of experience with the approach do not necessarily imply that there will be a positive attitude towards it.

This suggests a need for ongoing in-service professional development to bring TAs up to date about different aspects of the approach and their optimum implementation. Periodic retraining will be beneficial.

5. There was a low positive correlation between the TAs' professional training and their attitudes towards the approach. This made sense as the TAs reported that their programs had haphazard training practices or none at all. They differed a great deal in their responses to the types of training they received. Furthermore, 6 out of the 15 indicated that they did not consider themselves well trained for CLT, although they were expected to use it. 
In line with Chang (2011) and Jafari et al. (2015), the investigator believes that structured targeted training would have an impact on the TAs' attitudes and implementation. Systematic study of the theories of language and language learning are also essential as that will lead to a better understanding of the underlying principles.

TA training must therefore be well structured and consistent and include appropriate theoretical content.

The intent of this investigator is not to generalize but to use the data obtained from this sample to offer some insight into the attitudes of Spanish TAs towards CLT. This study has revealed very useful information that can serve as a guide for those in decision-making positions regarding TA recruitment, training, supervision, and support. Further research must be conducted in other contexts in order to provide an added depth to the subject matter and help ascertain more ways to address the issues.

\section{References}

Ahmad, S., \& Rao, C. (2013). Applying communicative approach in teaching English as a foreign language. A case study of Pakistan. Porta Linguarum 20, 187-203.

Ansarey, D. (2013). Communicative language teaching in EFL contexts: Teachers' attitude and perception in Bangladesh. ASA University Review 6(1), 61-78.

Borg, S. (2011). The impact of in-service teacher education on language teachers' beliefs. System 39(3), 370-380.

Brandl, K. (2008). Communicative language teaching in action: Putting principles to work. Upper Saddle River: Pearson Education.

Burke, B. M. (2012). Experiential professional development: Improving world language pedagogy inside Spanish classrooms. Hispania 95(4), 714-733.

Canale, M., \& Swain, M. (1980). Theoretical bases of communicative approaches to second language testing and teaching. Applied Linguistics 1(1), 1-47.

Carless, D. (2003). Factors in the implementation of task based teaching in primary schools. System 31, 485-500.

Chang, M. (2011). EFL teachers' attitudes toward communicative language teaching in Taiwanese College. Asian EFL Journal 53, 17-34.

Crookes, G. (1997). What influences what and how second and foreign language teachers teach? The Modern Language Journal 81(i), 67-79.

Darhower, M. (2014). Literary discussions and Advanced-Superior speaking functions in the undergraduate language program. Hispania 97(3), 396-412.

Derakhshan, A., \& Torabi, M. (2015). The implications of communicative language teaching: Teachers' perceptions in the spotlight. International Journal of English Language and Literature Studies 4(4), 203221.

Ellis, G. (1996). How culturally appropriate is the communicative approach? ELT Journal 50(3), 213-218.

Fox, C. (1993). Communicative competence and beliefs about language among graduate teaching assistants in French. Modern Language Journal 77, 313-324.

Freeman \& Richards. (1993). Conceptions of teaching and the education of second language teachers. TESOL Quarterly 25(2), 193-216.

Gardner R. C., \& Smythe, P. C. (1981). On the development of the Attitude/Motivation Test Battery. Canadian Modern Language Review 37, 510-525.

Glisan, E. (2013). On keeping the target language in language teaching: A bottom-up effort to protect the public and students. Modern Language Journal 97, 541-544.

Gokcora, D., \& Eveyik-Aydin, E. (2011). Arabic instructors' attitudes on communicative language teaching: Perspectives from an intensive language program. Saarbrücken, Germany: LAP LAMBERT.

Halliday, M. A. K. (1978). Language as social semiotic: The social interpretation of language and meaning. London: Edward Arnold.

Healy, A., et al. (1998). Toward the improvement of training in foreign languages. In A. Healy \& L. E. Bourne, Jr. (Eds.), Foreign language learning: Psycholinguistic studies on training and retention (pp. 3-56). Mahwah, NJ: Lawrence Erlbaum.

Holliday, A. (1994). The house of TESEP and the communicative approach: the special needs of state English language education. ELT Journal 48(1), 1-9. 
Jafari, S., Shokrpour, N., \& Guetterman, T. (2015). A mixed methods study of teachers' perceptions of communicative language teaching in Iranian high schools. Theory and Practice in Language Studies 5(4), 707-718.

Karavas-Doukas, E. (1996). Using attitude scales to investigate teachers' attitudes to the communicative approach. ELT Journal 50, 187-198.

Kleinsasser, R., \& Savignon, S. (1991). Linguistics, language pedagogy, and teachers' technical cultures. In J. E. Alatis (Ed.), Georgetown University Round Table on Languages and Linguistics (pp. 289-301). Washington, DC: Georgetown University Press.

Kramsch, C., \& Sullivan, P. (1996). Appropriate pedagogy. ELT Journal 50(3), 199-212.

Lee, M. (2014). Will communicative language work? Teachers' perceptions toward the new educational reform in South Korea. Indonesian Journal of Applied Linguistics 3(2), 1-17.

Li, D. (1998). It's always more difficult than you plan and imagine: Teachers' perceived difficulties in introducing the communicative approach in South Korea. TESOL Quarterly 32(4), 677-703.

Liao, X. (2003). Chinese secondary school teachers' attitude toward communicative language teaching and their classroom practice. Unpublished doctoral dissertation, University of Auckland, New Zealand.

Littlewood, W. (1981). Communicative language teaching: An introduction. Cambridge: Cambridge University Press.

Littlewood, W. (2007). Communicative and task-based language teaching in East Asian classrooms. Language Teaching 40, 243-249.

Littlewood, W. (2010). Chinese and Japanese students' conceptions of the 'Ideal English Lesson.' RELC Journal $41(1), 46-58$.

Lugo Cruz, G. (2017). Teaching assistants' perception of communicative language teaching (CLT) in an English as a SecondLanguage (ESL) university environment. Master's Thesis. St. Cloud State University.

Lyster, R., \& Ranta, L. (1997). Corrective feedback and learner uptake: Negotiation of form in communicative classrooms. Studies in Second Language Acquisition 19, 37-66.

Matthews, P. (2007). The Concise Oxford Dictionary of Linguistics. Oxford: Oxford University Press.

Meskill, C., \& Anthony, N. (2007). Learning to orchestrate online instructional conversations: A case of faculty development for foreign language educators. Journal of Computer Assisted Language Learning 20, 5-19.

Miller, L., \& Aldred, D. (2000). Student teachers' perceptions about communicative language teaching methods. RELC Journal 2, 1-19.

Ngoc, K., \& Iwashita. N. (2012). A comparison of learners' and teachers' attitudes toward communicative language teaching at two universities in Vietnam. University of Sydney Papers in TESOL 7, 25-49.

Nobuyoshi, J., \& Ellis, R. (1993). Focused communication tasks and second language acquisition. ELT Journal 47(3), 203-210

Nunan, D. (1987). Communicative language teaching: Making it work. ELT Journal 41, 136-145.

Ozsevik, Z. (2010). The use of communicative language teaching (CLT): Turkish EFL teachers' perceived difficulties in implementing CLT in Turkey. Unpublished Master's thesis, University of Illinois.

Pratt, C. (2008). In-class communicative projects. Upper Saddle River: Pearson Prentice Hall.

Pratt, C. (2017). Envisioning a future of re-examination of foreign language teacher education. Hispania 100(5), 268-269.

Querstret, D., \& Robinson, O. (2012). Person, persona and personality modification: An in-depth qualitative exploration of quantitative findings. Qualitative Research in Psychology 10, 140-159.

Rahimi, M., \& Naderi, F. (2014). The relationship between teachers' attitudes towards CLT and perceived difficulties of implementing CLT in language classes. International Journal of Applied Linguistics and English Literature 3(3), 237-245.

Raissi, R., Nor, F., Aziz, M., \& Saleh, Z., (2013). A comparison between students' and teachers' ideas regarding communicative language teaching implementation in Malaysian secondary schools: A qualitative survey. Journal of Basic and Applied Scientific Research 3(4), 608-614.

Richards, J. (2006). Communicative language teaching today. New York: Cambridge University Press.

Richards, J. C., \& Lockhart, C. (1994). Reflective teaching in second language classrooms. Cambridge: Cambridge University Press.

Richards, J., \& Rodgers, T. (2014). Approaches and methods in language teaching. Cambridge: Cambridge University Press. 
Sáfár, A., \& Kormos, J. (2008). Revisiting problems with foreign language aptitude. International Review of Applied Linguistics in Language Teaching 46, 113-136.

Sato, K. (2002). Practical understandings of CLT and teacher development. In Sandra J. Savignon (Ed.), Interpreting communicative language teaching: Contexts and concerns in teacher education (pp. 41-81). New Haven: Yale University Press.

Sato, K., \& Kleinsasser, R. (1999). Communicative language teaching (CLT): Practical understandings. Modern Language Journal 83, 494-517.

Savignon, S. (1972). Communicative Competence: An Experiment in Foreign-Language Teaching. Philadelphia: The Centre for Curriculum Development, Inc.

Savignon, S. (1983). Communicative competence: Theory and classroom practice. Reading, MA: AddisonWesley.

Savignon, S. (2002). Interpreting communicative language teaching: Contexts and concerns in teacher education. New Haven: Yale University Press.

Savignon, S., \& Wang, C. (2003). Communicative language teaching in EFL contexts: Learner attitudes and perceptions. IRAL 41, 223-249.

Schulz, R. (2000). Foreign language teacher development: MLJ perspectives-1916-1999. Modern Language Journal 84, 495-522.

Suk-Fun, W. (1998). Teachers' perceptions of communicative language teaching in Hong Kong secondary language classrooms: An investigation into the implementation of the syllabus for English (Forms I-V). Unpublished Master's thesis, University of Hong Kong.

Tedick, D. (2013). Embracing proficiency and program standards and rising to the challenge: A response to Burke. Modern Language Journal 97, 535-538.

Teschner, R. (1987). A profile of the specialization and expertise of lower division foreign language program directors in American universities. The Modern Language Journal 71(i), 28-35.

Thoms, J. (2011). Investigating foreign language graduate student instructors' perceptions and use of technology in the classroom. In Heather Willis Allen \& Hiram H. Maxim, (Eds.), Educating the future foreign language professoriate for the 21st Century (pp. 192-211). Boston: Heinle Cengage.

Tsai, T. H. (2007). Taiwanese educators' perspective on the implementation of the new English education policy. Unpublished doctoral dissertation, Alliant International University.

Valdés, G., González, S., López García, D., \& Márquez, P. (2003). The case of Spanish in departments of foreign languages. Anthropology \& Education Quarterly 34(1), 3-26.

Wyatt, M., \& Borg, S. (2011). Development in the practical knowledge of language teachers: a comparative study of three teachers designing and using communicative tasks on an in-service BA TESOL programme in the Middle East. Innovation in Language Learning and Teaching 5(3), 233-252.

Yu, L. (2001). Communicative language teaching in China: Progress and resistance. TESOL Quarterly 35(1), 194198. 